\title{
Culinary travel experiences, quality of life and loyalty
}

\section{Experiencias turísticas gastronómicas, calidad de vida y lealtad}

\author{
José Manuel Hernández-Mogollón, Elide Di-Clemente and \\ Ana María Campón-Cerro \\ Department of Business Management and Sociology, \\ Universidad de Extremadura, Badajoz, Spain
}

\begin{abstract}
Purpose - This paper aims to develop an original model in the context of food-based experiences considering new experiential variables, such as to experience quality, memorability and quality of life (QOL), and their impact on marketing outcomes, namely, satisfaction and loyalty, approached from an experience perspective.

Design/methodology/approach - An empirical approach has been adopted. Data have been collected through an online and a paper-and-pencil method, using an original questionnaire addressed to tourists who had a food-based experience during their recent holidays. Partial least squares-structural equation modelling is the technique used for data analysis.

Findings - The results confirm that local food, enjoyed through quality experiences, is a determining factor in designing memorable products, achieving tourist satisfaction, improving their $\mathrm{QOL}$ and encouraging loyalty to experiential food-based practices.

Research limitations - Results should be interpreted within the context of this research because of the use of a sample conveniently selected.

Practical implications - Gastronomic experiences represent a successful strategic resource for tourist destinations and professionals who want to adapt their business/destination to the new requirements of the experiential context.

Originality/value - To the best of authors' knowledge, this study is first to relate the impact of memorable and quality culinary experiences on the QOL of tourists, chasing, as a final result, loyal intentions towards a specific kind of experience (culinary) rather than towards the destination.
\end{abstract}

Keywords Partial least squares (PLS), Quality of life, Culinary tourism, Memorability, Experience loyalty, Experientiality

Paper type Research paper

C José Manuel Hernández-Mogollón, Elide Di-Clemente and Ana María Campón-Cerro. Published in Spanish Journal of Marketing - ESIC. Published by Emerald Publishing Limited. This article is published under the Creative Commons Attribution (CC BY 4.0) licence. Anyone may reproduce, distribute, translate and create derivative works of this article (for both commercial and noncommercial purposes), subject to full attribution to the original publication and authors. The full terms of this licence may be seen at http://creativecommons.org/licences/by/4.0/legalcode

The authors acknowledge the funding by the European Regional Development Fund (ERDF) and Junta de Extremadura (Spain), Consejería de Economía Ciencia y Agenda Digital (Reference No. GR18109).

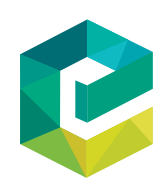

Spanish Journal of Marketing - 


\section{Resumen}

Propósito - Este trabajo propone un modelo original en el contexto de las experiencias gastronómica que relaciona nuevas variables experienciales - Calidad de la Experiencia (EXPQ), Memorabilidad (MEM) y Calidad de vida (QOL) - con variables de resultado tradicionales del marketing turístico: satisfacción y lealtad, consideradas desde un nuevo enfoque experiencial.

Diseño/Metodología/Enfoque - Se ha optado por un enfoque empírico. Los datos han sido obtenidos por medio de una encuesta online y en papel, con un cuestionario original dirigido a turistas que han vivido una experiencia gastronómica en sus recientes vacaciones. Los datos han sido tratados con PLS-SEM.

Hallazgos - Los resultados alcanzados confirman que las experiencias gastronómicas de calidad son un factor determinante para diseñar productos turísticos memorables, lograr la satisfacción de los turistas, mejorar su calidad de vida e incentivar la lealtad hacía prácticas experienciales vinculadas a la gastronomía.

Limitaciones - Debido al uso de una muestra no-probabilística de conveniencia los resultados de este estudio sufren limitaciones en cuanto a su generalización.

Implicaciones practicas - Las experiencias gastronómicas representan un recurso estratégico para los destinos turísticos y los profesionales del sector que quieran adaptar su negocio/destino a las nuevas exigencias del entorno experiencial.

Originalidad - Este trabajo relaciona por primera vez el impacto de las experiencias gastronómicas memorables y de calidad en la calidad de vida de los turistas, planteando como resultado final la lealtad al tipo de experiencia, más que la intención de volver a visitar el destino.

Palabras clave Experiencialidad, Turismo gastronómico, Memorabilidad, Calidad de vida, Lealtad experiencial, Ecuaciones estructurales (PLS)

Tipo de artículo Trabajo de investigación

\section{Introduction}

Nowadays, tourism is evolving from being a service-centric industry into an experiencecentric one (Clatworthy, 2019). Products, to be successful, must deliver intangible values, more than high-end functional properties (Lashley, 2008; Palmer, 2010).

Hospitality and tourism products are experiential in their own essence (Williams, 2006). However, the experiential trend is introducing important changes in the way tourism organisations and destinations design and market their offerings, as well as the impact that the experience-based consumption may have on behavioural intentions (Serra-Cantallops et al., 2018). One of the most sought results in tourism marketing has been the loyalty towards a destination expressed in terms of intentions to recommend or repeat the visit in the future (Alves et al., 2019). The new experiential push exerts a centrifugal effect with respect to the visited destinations and encourages, instead, curiosity towards the newness.

Therefore, within the new experiential context, it seems interesting to look at different results than destination loyalty and explore the loyal intentions towards a specific practice that consumers reiteratedly choose in their trips.

Culinary tourism seems to be a typology especially likely to develop experiential proposals, as it can involve tourists in hands-on activities. Nowadays, food tourism has established as one of the most solid expressions of the tourism demand (Stone et al., 2019) and the desire to travel with a food-based motivation is one of the biggest paradigms of the current tourism industry (Kim et al., 2009).

Food consumption on holidays is no longer considered as a practice to address the need of nourishment but rather a germane aspect of the holiday experience, with potentially lasting effects on individuals' lives (Di-Clemente et al, 2019b) and future behaviours (Stone et al., 2019).

Food is a resource capable of engaging tourists. Such is the case that there exists a proper segment of consumers - the foodies - whose travel decisions are strongly determined by the desire of tasting typical products, learning about local culinary cultures and testing themselves with new cooking practices. 
The engaging potential of food tourism finds an explanation in its memorable power (Adongo et al., 2015) and impact on individuals' quality of life (QOL) (Di-Clemente et al., 2019b; Mkono et al., 2013).

The contact with local food and culinary cultures while on holidays has a determining role in the way travellers experience a destination (Kivela and Crotts, 2006; Wijaya et al., 2017) and generates pleasant memories (Stone et al., 2017). If travelling experiences are perceived as memorable, the positive emotions associated with them last beyond the journey, impact the perceptions of personal QOL (Dolnicar et al., 2013) and, in turn, drive positive future behaviours (Björk and Kauppinen-Räisänen, 2016; Widjaja et al., 2018).

The scientific literature confirms the connection between food experiences and memorability (MEM) and explores how this can positively impact the destination image and drive the tourists' intentions to purchase local food (Stone et al., 2019).

However, the tourists' assessment of the food experiences lived on holidays and their effects beyond the journey, in terms of innovative experiential marketing outcomes, such as experiential satisfaction and loyalty and QOL, remain still unexplored and require further research (Sthapit et al., 2017). To fill this gap, this research puts forward the idea that high quality and memorable culinary experiences can satisfy the expectations of experiential tourists as they:

- enhance individuals' QOL; and

- drive new loyal behaviors towards a specific typology of experience, i.e. food-based, rather than towards the destination.

This approach to behavioral intentions is original and seems more consistent with the quest of novelty and uniqueness elicited by the current experiential stream (Pearce and Kang, 2009).

Considering the preceding, the main goal of this research is to find out whether experiential encounters with local food have a positive impact on marketing outcomes such as satisfaction, but also on innovative, more emotion-based outcomes, such as MEM, QOL and experience loyalty (EXPLOY).

The contribution of this study is to empirically test whether food experiences, lived on holidays, can be positively linked with MEM and QOL and, in turn, drive loyal intentions towards a specific experiential practice, more than focussing on destination loyalty, traditionally chased in tourism marketing research.

\section{Theoretical background and hypotheses definition}

Experientiality is defining a new competitive scenario for tourist destinations and businesses (Castañeda García et al., 2018). New management and marketing tools are required to be able to meet the new requirements of the sector. The present work outlines a conceptual model which, in the context of food tourism, has in experiential quality its input variable and in MEM, QOL and experiential marketing outputs (satisfaction and loyalty) its endogenous variables.

\subsection{Food tourism}

Food tourism, also termed as gastronomic or culinary tourism, has become one of the emerging forms of tourism (Baah et al., 2019) as a significantly growing number of tourists travelling to a destination with the unique motivation of tasting its local products and cuisine (Hall et al., 2003).

From a scientific perspective, food tourism is a research topic of great interest owing to its potential power in destination branding (Björk and Kauppinen-Räisänen, 2016), its capability of extending the stay of tourists at a certain destination (Ignatov and Smith, 2006), the diversity of activities and events that can be drawn around local products (Mason and Paggiaro, 2009), and its implication with the sustainable development of a destination (Hjalager and Johansen, 2013).
Culinary travel experiences 
Richards (2012) emphasises the important role of food in the new experience economy, noting that as this last has developed, so too the interest in traditional foods. Therefore, food-based tourism can be considered one of the best expressions of a new experiential approach to tourist consumption. In addition, the increasing interest in well-being and its connection with tourism experiences has developed a new trend on food and defined a new group of consumers who look at food not just for its functional value but rather as a central aspect in their lives, both during holidays and daily life.

According to Sthapit et al. (2017), food consumption in hospitality and tourism has been largely approached from the supply-side perspective, while the assessment of food experiences by tourists deserves further attention especially when the tourists' interest in local food has given birth to a proper market segment: "the foodies", those travellers who show a prominent interest towards culinary heritages and consider gastronomy as a complex and cultural experience (Fox, 2007; López-Guzmán and Sánchez-Cañizares, 2012). This tourism practice is assuming a growing importance in the travel industry, as it has a great potential for the design of experiential products. Food encounters are likely to be sensorial experiences that can be stored in tourists' minds as memorable (Stone et al., 2019) and happy moments (Mkono et al,, 2013). Eating is nowadays associated with a requirement for happiness (Carrillo et al, 2013), as the engagement in food experiences promotes exploration (Kim et al, 2012), which has to do with the desire of knowledge. Learning is the most sought experience by tourists as it adds to personal accomplishment and self-esteem (Adongo et al., 2015). In this line, memorable food experiences are valuable QOL's enhancers and effective determinants of positive behavioural intentions (Tsai, 2016; Di-Clemente et al., 2019a, 2019b).

\subsection{Experience quality}

Within tourism and recreation research, the concept of quality, and specifically service quality, has been considered one of the major determinants of satisfaction and future behaviours (Alves et al., 2019). With the rise of the experience economy, researchers and practitioners are facing some challenges in assessing the EXPQ, as it deeply differs from service quality. Komppula (2006) states that, for experiential products, emotional aspects are more influential than functional ones. From a theoretical perspective, EXPQ has been defined as the consumer's affective response to the desired social-psychological benefits and a psychological outcome for tourism customers (Fernandes and Cruz, 2016; Jin et al., 2015). Dong and Siu (2013) confirm that a favourable evaluation of the experience will drive positive feelings which, in turn, will leave pleasant memories and happiness. Chen and Chen (2010) and Chen and Chen (2013) state that EXPQ may exert a positive impact on tourism businesses' performances, as it can improve tourists' satisfaction and loyalty. Thus, the concept of EXPQ deserves further attention in both its theoretical definition and empirical application. The scientific literature offers some early attempts to conceptualise and measure EXPQ. Kao et al. (2008) apply theatrical elements to the process of creating tourism experiences and propose immersion, surprise, participation and fun as essential elements. Cole and Scott (2004) define EXPQ using entertainment, education and community benefits, finding that the construct fully mediates the relationship between service performance and tourist's satisfaction. Wu and colleagues (Wu and Ai, 2016; Wu et al., 2018) confirms the relation linking EXPQ and experience satisfaction.

By the other hand, according to Pizam (2010), the quality of the experience is what turns it memorable. Therefore, $\mathrm{EXPQ}$ is assumed to be a proper antecedent for memorable experiences.

In addition, following Cole and Scott (2004), the quality of the experience is determined by its capability to entertain and educate tourists. In turn, the chance to learn something new on holidays is a determinant for self-esteem or enhancements in QOL (Kim et al., 2012). 
According to the preceding, it seems worthy to consider a connection between EXPQ and tourists' perceptions of their QOL.

Within the specific context of culinary tourism, the number of works that test the quality of culinary experiences and its impacts on outcome variables are still scarce. Widjaja et al. (2018) show some initial insights confirming that EXPQ directly and positively influences the satisfaction with culinary experiences, which, in turn, has a positive effect on future behaviours. Similarly, few works recently published, stress the role of food-based activities lived on holidays as extraordinary experiences (Goolaup et al., 2017) and effective memory enhancers (Stone et al., 2019; Tsai, 2016; Williams et al., 2018). The causal path linking the quality of culinary experiences and QOL find some support on previous research from a theoretical perspective, however, its empirical demonstration is an original contribution of this research.

The following hypotheses are posited:

H1. Experience quality exerts a positive impact on experience satisfaction.

H2. Experience quality exerts a positive impact on memorability.

H3. Experience quality exerts a positive impact on quality of life.

\subsection{Memorability}

At the present time, one of the most pushing topics in experiential tourism is the identification of those aspects capable of turning a trip or a holiday into a memorable experience (Kim and Ritchie, 2014). MEM of the tourism activities can generate long-lasting memories and have a positive impact on the tourists' assessment of the experience (Kim, 2010). Several contributions in the marketing literature offer supporting evidence of how MEM of the experiences induce positive outcomes in tourism, in terms of satisfaction (Quadri-Felitti and Fiore, 2013; Ali et al., 2016) and perceived feeling of increased happiness (Knobloch et al., 2017; Nawijn et al., 2010). Nawijn et al. (2010) explain that after the holiday, the recollection phase is a crucial moment when tourists can remember and revive positive experiences which, in turn, will increase tourist's long-lasting happiness. Knobloch et al. (2017) confirm that memorable tourism experiences have eudaimonic effects, that is, provide a feeling of fulfilment which leads to personal growth, which, in turn, influences people's well-being beyond the consumption. More specifically, Nawijn (2011) confirms that tourism experiences contribute to everyday happiness through memories and reminiscences triggered by physical objects (photographs and souvenirs) which relight the happiness associated with past travel experiences.

According to Stone et al. (2017), food-based experiences are highly connected with memory and found that they play a greater role in satisfaction than other in-trip activities. The chance to get in contact with new flavours allows tourists to gain a sensorial enjoyment of local culture which facilitates the formation of positive memories and has the potential of driving future behavioural intentions (Sthapit et al., 2017; Tsai, 2016).

In addition, Sthapit and Coudounaris (2017) state that there exists an incipient research stream exploring how memories of holidays enhance individuals' subjective well-being.

Nevertheless, the links between these two variables have not yet been explored in the specific context of food experiences, finding few antecedents in the works published by Lin (2014) and Sthapit (2018). Lin (2014) confirms that food experiences are stimuli eliciting psychological well-being. Sthapit (2018) found that memories related to food-holidays contribute to individual subjective well-being. 
In line with these considerations, this research considers that food-based experiences can provide memorable moments which, in turn, enhance tourists' satisfaction and QOL. Thus, the following hypotheses are posited:

H4. Memorability exerts a positive impact on experience satisfaction.

H5. Memorability exerts a positive impact on quality of life.

\subsection{Experience satisfaction}

According to Kao et al. (2008), experiential satisfaction (EXPSAT) is a conceptual extension of service satisfaction focussed on consumers' overall evaluation of the experience after consumption. Experientiality is suggesting a change in the way satisfaction is conceived, requiring a more emotion-based assessment of this variable. New affective values are gradually integrating (Hosany and Gilbert, 2010) or even substituting, the traditional utilitybased approach to satisfaction (Agapito et al., 2013; Bigné et al., 2008). The scientific literature shows that a growing consensus exists on the need of incorporating emotional components in the measurement of satisfaction in tourism (de Rojas and Camarero, 2008) and several studies have already empirically proved the relationship between emotions and satisfaction (Hosany, 2012). Satisfaction is often considered a significant determinant of loyalty and future behaviours (Chi and Qu, 2008; Cronin et al., 2000). Providing satisfying experiences will possibly drive loyal behaviours in the future. According to Aziz et al. (2012), experiential satisfaction determines the visitors' loyalty. In addition, the findings achieved by Jin et al. (2015), Wu and $\mathrm{Li}$ (2017) and $\mathrm{Wu}$ et al. (2018) suggest that experiential satisfaction induces tourists' loyal behaviours. Food, because of the sensorial involvement that requires to be enjoyed by tourists, is particularly given to provoke an emotional reaction in consumers and the achievement of an emotion-based satisfaction. Accordingly, the following hypothesis is established:

H6. Experiential satisfaction exerts a positive impact on experience loyalty.

\subsection{Quality of life}

Research on happiness and related concepts has traditionally been a "playground for speculative philosophy" (Veenhoven, 2009). However, it has recently caught the attention of social scientists (Nawijn et al., 2010) as the travel industry is selling products that go far beyond the achievement of satisfaction and loyal intentions, it is rather selling moments capable of determining how people feel and how fulfilling they perceive their lives (Nawijn et al., 2013). Research in tourism has largely confirmed that individuals benefit from taking holiday (Chen and Petrick, 2016; Chen et al., 2016). In tourism literature, there is a consensus on considering tourism experiences as QOL's enhancers (Kruger et al., 2013; Uysal et al., 2016). Kim et al. (2015) confirmed that, among elderly tourists, QOL's enhancements experienced while on holidays have an impact on future behaviours. Lam and So (2013) found a positive relationship between life satisfaction and word-of-mouth, which is a loyalty's indicator. More specifically related to the present research context, Lin (2014) found that culinary experiences lived on holidays exert a positive effect on the tourists' psychological well-being which, in turn, can determine future loyal behaviours. Similarly, Kim et al. (2012) found that well-being perceptions related to a dining out experience are the most powerful determinants of positive behavioural intentions. 
Considering the preceding, the present research assumes that the perceived enhancements of QOL, attributable to the culinary experience lived, may positively influence future loyal behaviours of travellers towards this kind of in-trip activity. Therefore, the following hypothesis is posited:

H7. Quality of life exerts a positive impact on experience loyalty.

2.6 Experience loyalty

Oliver (1993, p. 34) defines loyalty as a "commitment to re-buy or re-patronise a preferred product/service consistently in the future [...]”. According to Flavián et al. (2011), loyalty is regarded as the measure of the success of marketing strategies. The recent experiential trend in tourism brings traveller to seek unique holidays' experiences and ever-new destinations, thus loyal behaviours, intended as the willingness to repurchase and revisit is a hard goal to achieve. Experientiality posits the following issues related to loyalty:

- novelty seeking and wanderlust are motivators for experiential tourists and discourage revisiting the same destination in the future (Pearce and Kang, 2009); and

- experiences are the principal products considered by experiential tourists; therefore, people may develop loyal attitudes towards a particular type of experience rather than to a destination or service (McKercher et al., 2012).

Culinary tourism gives the chance to explore loyalty towards a specific kind of experience: food-based practices. Food tourists can possibly develop loyal attitudes towards specific experiential activities, linked to local gastronomy and cuisine and be willing to rebuy a similar experience in their next travels. Considering the preceding, this research aims at testing the causal paths linking the EXPSAT with memorable and quality food-based activities, and the perceived enhancements in QOL, as effective antecedents of EXPLOY, considering this last as the tourists' intentions to patronise the experience, more than the revisit of the same destination.

The hypotheses and theoretical model of the research are depicted in Figure 1.

\section{Methodology}

\subsection{Sampling strategies and data collection}

The population of the study is represented by all those tourists who had at least one culinary experience during one of their holidays or trips. The sampling strategy adopted is of convenience. The food-based experiences considered in the research have been selected with a web search aimed at identifying food and drink tours, gastronomic routes, tasting experiences, culinary tours, cooking classes and workshops which allow participants to have a deep contact with the culinary cultures of the destination visited. A total of 75 experiences were selected and their participants intercepted on the Facebook® page of the enterprises providing the experiences and requiring their opinions about the experience lived. The link of the survey has been placed as a response to the tourists' review or comment left on the Facebook wall of the enterprise providing the experience. Facebook has been chosen as the tool for the dissemination of the survey as it brings together a virtual community with over 800 million users and its popularity provides researches with the chance to reach a significant and international sample (Kane et al., 2012). Data have been collected with an original and structured questionnaire which has previously undergone a process of pre-test (15 experts among academics and practitioners) and trial (17 people of 


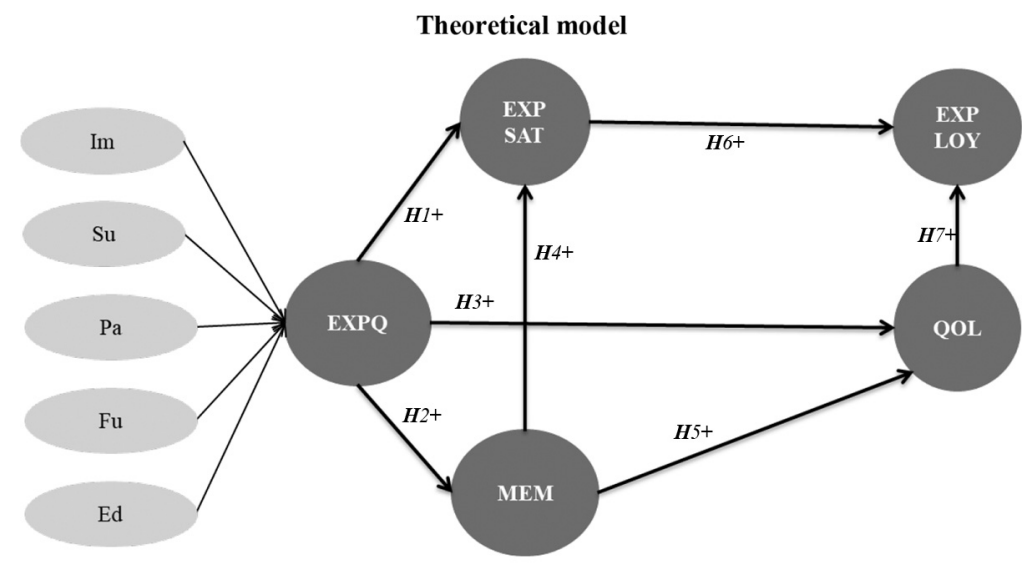

Figure 1.

Theoretical model

Notes: Im, immersion; Su, surprise; Pa, participation; Fu, fun; Ed, education;

EXPQ, experience quality; EXPSAT, experience satisfaction; MEM, memorability; QOL, quality of life; EXPLOY, experience loyalty

different ages and nationalities) to ensure the effectiveness of the tool. Data collected online have been completed with a paper-and-pencil method, used to cover one experience and that allowed to reach a larger and more reliable sample. The two groups of data have been treated as a unique sample based on the results of a Levene's test that confirmed the homogeneity of their variances. Table 1 shows the technical details of the empirical work conducted.

\subsection{Measurement scales}

Following the recommendations put forward by Preston and Colman (2000) a seven-point Likert scale was adopted for measurements. The construct dimensionality considered for the measurement of EXPQ is a composition resulting from the ones proposed by Kao et al. (2008) and Cole and Scott (2004) including variables such as immersion, surprise, participation, fun and education, which seek to assess quality from a new experiential perspective. To measure memorability, this research adopts a three-item, one-dimensional approach, whose validity has already been tested by Oh et al. (2007), Hosany and Witham

Population

Geographical scope

Data collection method

Sampling frames

Informants

Population size

Table 1.

Technical details of data collection
Sampling technic

Fieldwork

Achieved entries

Valid entries
Tourists who had at least one culinary experience during one of their holidays or trips

International

Online and paper-based survey

Not available

Tourists who had at least one culinary experience during one of their holidays or trips

Unknown

Non-probability convenience sampling

March-September 2016

563

425 
(2010), Loureiro (2014), Ali et al. (2016) and Quadri-Felitti and Fiore (2013). The operationalisation proposed by these last authors is the one selected in this study because of the suitability of the items and the similarity of the study context (wine routes). With regard to the measurement of experiential satisfaction, this construct must assess the integral evaluation and contentment that tourists perceive with regard to the food-based experience lived (Kao et al., 2008). Kim et al. (2015) offer a significant support to the conceptual and empirical approach of this variable; therefore, the satisfaction with the experience proposed by these authors appears to be the most appropriate scale to assess experiential satisfaction in the present research. QOL measures the impact that culinary experiences can have into the individuals' personal evaluation of their lives. Measurements adopted here are based on the QOL's scale proposed by Sirgy et al. (2011) and slightly adapted to match the study context. The dominant approach in loyalty measures in tourism is a two-dimensional one, considering both the behavioural and the attitudinal dimension (Mechinda et al., 2009). Considering the experiential nature of this study, the behavioural dimension of this variable is not applicable, thus the measurement of EXPLOY is proposed accordingly with the attitudinal scale proposed by Mechinda et al. (2009) and largely validated in tourism studies.

\subsection{Data analysis}

Data have been treated with both IBM-SPSS Statistics Version 21, for descriptive analysis, and Partial least squares-structural equation modelling (PLS-SEM) for multivariate analysis, applied to test the predictive value of the model hypothesised. PLS-SEM was the selected method as it could suit the study better than covariance-based structural equation modelling (CB-SEM) considering that: it can be used in exploratory studies, is focussed on prediction, and works with small samples (Hair et al., 2012). SmartPLS 3 is the statistical software used for the assessment of the structural model (Ringle et al., 2015).

\section{Results}

\subsection{Characteristics of the sample}

The sample achieved for this research features a total number of 563 individuals, of which 425 were valid and used in this analysis. Table 2 shows in detail the sociodemographic characteristics of the sample.

The female respondents $(61.9 \%)$ outnumber male respondents $(28.9 \%)$. The majority of the sample is comprised between the age range from 41 to $50(24.7 \%)$, closely followed by those from 31 to $40(21.9 \%)$. Most respondents are from the USA (26.4\%), Italy $(18.6 \%)$, Spain $(10.6 \%)$ and Great Britain $(7.3 \%)$. In general, data about place of origin are quite heterogeneous and many nationalities are represented by just one or few individuals. Most of the respondents declared to have a University level degree (65.9\%). The majority of the sample lived their culinary experience in $2016(33.4 \%)$ and $2015(31.3 \%)$ which indicates that it was recent and easy to be recalled at the moment of responding the questionnaire. Italy (35.1\%), Spain (16.9\%) and Thailand (8.5\%) are the countries where the major part of the sample decides to live a food-based experience as a part of their holidays. "Food tour" is the most popular activity chosen (53.9\%), followed by "Cooking class" (32.9\%), "Tastings" $(6.8 \%)$ and "Others" (5.6\%), which includes food workshops, show cooking, etc.... This feature confirms that those tourists interested in local gastronomy, search for a participative approach to typical food, and expect something more than just sampling traditional cuisine and eating at local restaurants. 


\begin{tabular}{|c|c|c|c|c|}
\hline \multirow{5}{*}{$\begin{array}{l}\text { SJME } \\
24,3\end{array}$} & Variables & Answers & Frequency & $(\%)$ \\
\hline & Gender $(n=386)$ & Male & 123 & 28.9 \\
\hline & & Female & 263 & 61.9 \\
\hline & & Missing values & 39 & 9.2 \\
\hline & Age $(n=389)$ & Up to 30 & 66 & 15.5 \\
\hline \multirow{18}{*}{434} & & From 31 to 40 & 93 & 21.9 \\
\hline & & From 41 to 50 & 105 & 24.7 \\
\hline & & From 51 to 60 & 71 & 16.7 \\
\hline & & Over 60 & 54 & 12.7 \\
\hline & & Missing values & 36 & 8.5 \\
\hline & Country of residence $(n=386)$ & USA & 112 & 26.4 \\
\hline & & Italy & 79 & 18.6 \\
\hline & & Spain & 45 & 10.6 \\
\hline & & UK & 31 & 7.3 \\
\hline & & Other nations & 118 & 28 \\
\hline & & Missing values & 39 & 9.2 \\
\hline & Education $(n=387)$ & Compulsory education & 12 & 2.8 \\
\hline & & High school & 65 & 15.3 \\
\hline & & University & 280 & 65.9 \\
\hline & & Other & 30 & 7.1 \\
\hline & & Missing values & 38 & 8.9 \\
\hline & Year of the experience $(n=425)$ & 2016 & 142 & 33.4 \\
\hline & & 2015 & 133 & 31.3 \\
\hline & & 2014 & 74 & 17.4 \\
\hline Table 2. & & 2013 & 41 & 9.6 \\
\hline Characteristics of the & & 2012 & 17 & 4.0 \\
\hline sample & & $<2012$ & 18 & 4.2 \\
\hline
\end{tabular}

\subsection{Model estimation}

The application of the SEM procedure implies the assessment of the measurement and the structural model (Hair et al., 2012) to test the validity and predictive power of the hypothesised model.

4.2.1 Measurement model assessment. The hypothesised model treats EXPQ as a second-order construct. To assess multidimensional variables, SmartPLS requires the application of a specific process: the two-step approach which implies that the dimensions of a multidimensional construct act like the second-order variables they represent.

Step 1. The second-order variable is substituted by its corresponding first-order dimensions. At this stage, all the constructs included in the model are reflective; therefore, the measurement model assessment has to be done with regard to individual item reliability, internal consistency reliability, convergent validity (Table 3) and discriminant validity (Table 4). The individual item reliability $(\lambda)$ shows acceptable values, above the threshold of 0.707 fixed by Carmines and Zeller (1979). With regard to composite reliability, all the values are within the critical levels set at $0.7-0.9$ or $0.6-0.7$ for exploratory studies (Nunnally and Bernstein, 1994). According to Hair et al. (2011), significant values for convergent validity should be higher than 0.50 , which signifies that each construct explains at least half of the variance of its indicators. All the recorded scores are above the critical value. Finally, discriminant validity is assessed with the $\mathrm{HTMT}_{1}$ (Franke and Sarstedt, 2019). All the values are acceptable as they are different from 1, as shown in Table 4.

Step 2. At this point, the subdimensions of the second-order construct (EXPQ) included in the model are substituted by an average score and act as indicators of the second-order 


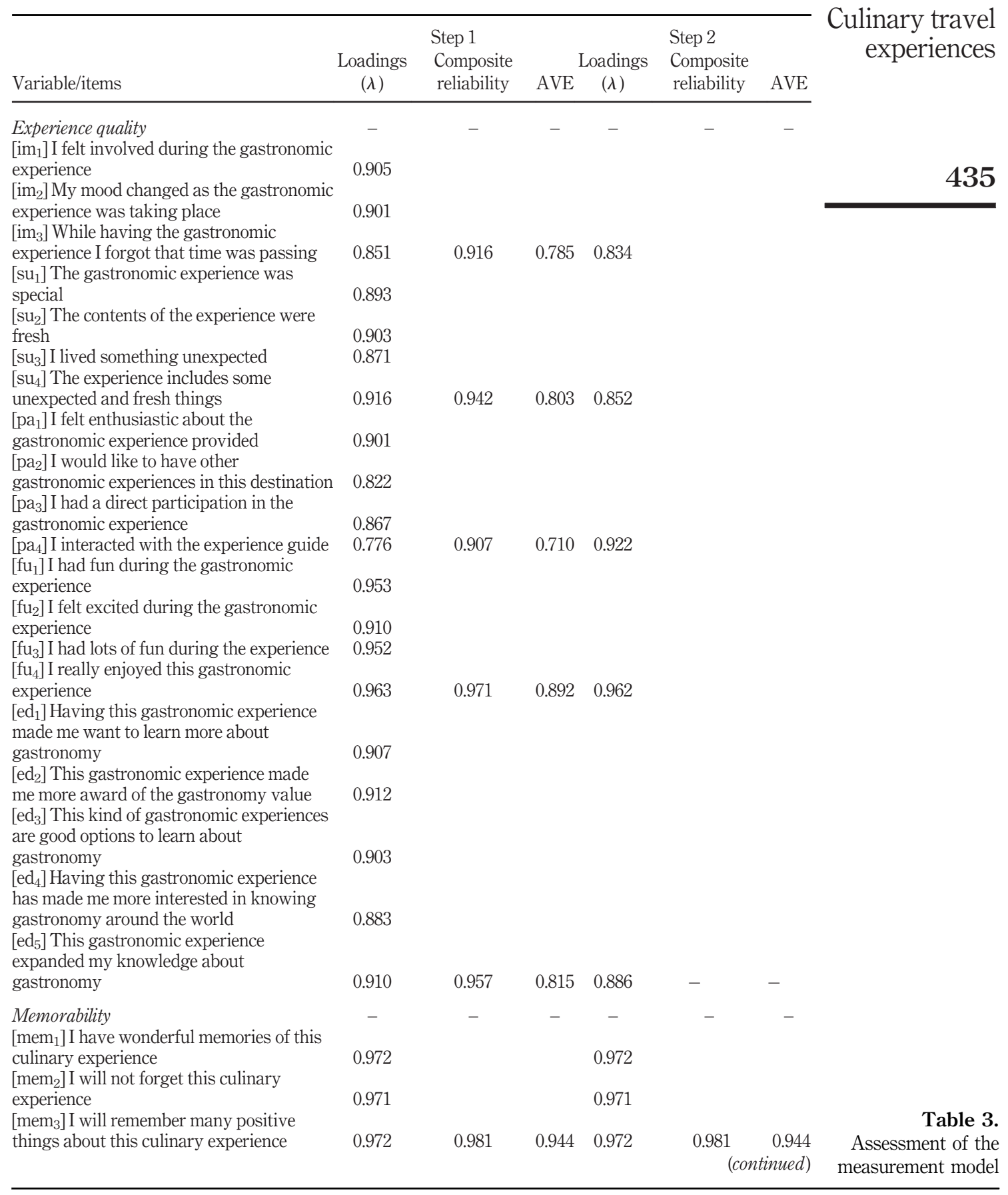




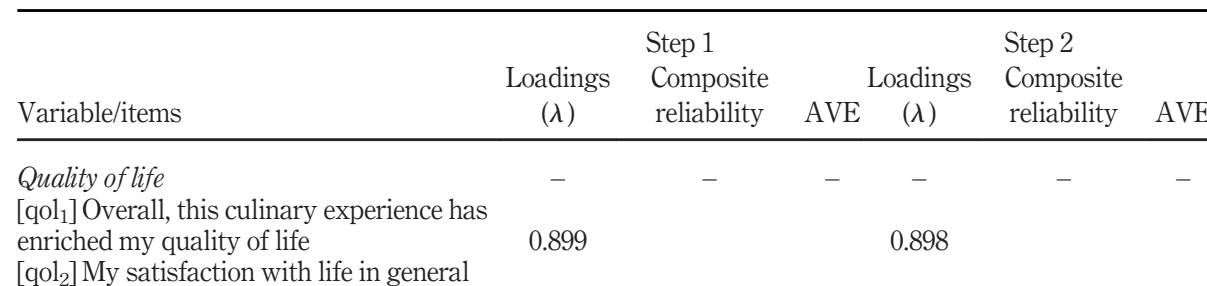

$\left[\mathrm{qol}_{2}\right] \mathrm{My}$ satisfaction with life in general

was increased after this culinary experience

0.902

0.899

[qol $]_{3}$ Although I have my ups and down, in general, I feel good about my life after this culinary experience

$\left[\mathrm{qol}_{4}\right]$ After this experience I feel that I lead a meaningful and fulfilling life.

[qol $\left.{ }_{5}\right]$ Overall, I felt happy upon my return from this culinary experience

\section{Experience satisfaction}

[expsat ${ }_{1}$ My overall evaluation on the gastronomic destination I visited is positive

[expsat 2 My overall evaluation on this gastronomic experience is favourable [expsat ${ }_{3}$ I am satisfied with this gastronomic experience [expsat ${ }_{4}$ I am pleased with this gastronomic experience

\section{Experience loyalty}

[exploy 1 I consider myself a loyal consumer of gastronomic experiences [exploy2] My next trip will most likely include a gastronomic experience [exploy3] I would have more gastronomic experiences in the future [exploy4] I would recommend to have this gastronomic experience to people who seek my advice [exploy5] I would tell others positive things about this gastronomic experience

0.913

0.881

0.817

-

0.951

0.970

0.974

0.973

0.776

0.870

0.898

0.908

0.881

Notes: Im, immersion; Su, surprise; Pa, participation; Fu, fun; Ed, education; EXPQ, experience quality;

Table 3. EXPSAT, Experience satisfaction; MEM, memorability; QOL, quality of life; EXPLOY, experience loyalty

variable. The new nomological structure of the model needs to be re-assessed in its measurement validity and reliability, considering that now EXPQ is a formative construct and needs to be assessed by calculating the items' weights (Hair et al., 2012) and the variance inflation factor (VIF) (Henseler et al., 2009). VIF resulted to be acceptable being lower than 5 (Hair et al., 2012), with an exception in Participation which little exceeds this threshold and that can be still acceptable according to Hair et al. (1995) who fix the threshold at 10 . Weights are significant according to the thresholds of a one-tailed $t$-test (Table 5) performed with a 5,000-sample bootstrap, with an exception in Immersion which shows a nonsignificant value. However, the two items will not be dropped following the recommendation 
made by Roberts and Thatcher (2009) who state that non-significant items should be kept in the measurement model as formative indicators are not interchangeably and dropping an indicator implies dropping a part of the construct. In addition, Hair et al. (2014) maintain that formative items should not be dropped if their loadings $(\lambda)$ are higher than 0.5 (Table 3 ). For the assessment of the reflective constructs, the same steps implemented for the measurement of the first-order model (Step 1) must be followed. Individual item reliability, internal consistency, convergent validity (Table 3) and discriminant validity (Table 6) show acceptable value.

4.2.2 Structural model assessment. Structural model is assessed with regard to $R^{2}$ for each dependent variable and the significance of the paths $(\beta) \cdot R^{2}$ informs about the model's

Culinary travel experiences

\begin{tabular}{|c|c|c|c|c|c|c|c|c|c|c|}
\hline & IM & $\mathrm{SU}$ & PA & $\mathrm{FU}$ & $\mathrm{ED}$ & MEM & EXPSAT & QOL & EXPLOY & \\
\hline \multicolumn{11}{|l|}{$I M$} \\
\hline$S U$ & 0.856 & & & & & & & & & \\
\hline$P A$ & 0.944 & 0.933 & & & & & & & & \\
\hline$F U$ & 0.842 & 0.770 & 0.897 & & & & & & & \\
\hline$E D$ & 0.831 & 0.784 & 0.877 & 0.822 & & & & & & \\
\hline MEM & 0.795 & 0.788 & 0.879 & 0.895 & 0.794 & & & & & \\
\hline EXPSAT & 0.789 & 0.741 & 0.864 & 0.914 & 0.777 & 0.897 & & & & \\
\hline$Q O L$ & 0.619 & 0.652 & 0.694 & 0.577 & 0.691 & 0.659 & 0.590 & & & \\
\hline EXPLOY & 0.699 & 0.663 & 0.788 & 0.668 & 0.766 & 0.699 & 0.705 & 0.734 & & $\begin{array}{l}\text { 1able } 4 . \\
\text { Discriminant validity }\end{array}$ \\
\hline \multicolumn{11}{|c|}{$\begin{array}{l}\text { Notes: IM, immersion; SU, surprise; PA, participation; FU, fun; ED, education; EXPQ, experience quality; } \quad \text { analysis (HTMT1) } \\
\text { EXPSAT, experience satisfaction; MEM, memorability; QOL, quality of life; EXPLOY, experience loyalty }\end{array}$} \\
\hline
\end{tabular}

\begin{tabular}{|c|c|c|c|c|c|}
\hline Construct & Items & VIF & Weights & $t$-test ${ }^{*}$ (weights) & Loadings $(\lambda)$ \\
\hline \multirow{5}{*}{ EXPQ } & Ed & 3.371 & $0.204^{\text {***** }}$ & 3.386 & 0.886 \\
\hline & $\mathrm{Fu}$ & 3.736 & $0.532^{* * * * *}$ & 7.221 & 0.962 \\
\hline & Im & 3.627 & $-0.015 \mathrm{~ns}$ & 0.241 & 0.834 \\
\hline & $\mathrm{Pa}$ & 5.821 & $0.218^{*}$ & 2.698 & 0.922 \\
\hline & $\mathrm{Su}$ & 3.789 & $0.140^{* *}$ & 2.223 & 0.852 \\
\hline
\end{tabular}

Notes: Critical values for a one-tailed $t$ test: values: ${ }^{*} p<0.05^{* * *} p<0.01{ }^{* * * *} p<0.001 ; 1.645 \rightarrow 10 \%$ level of significance; $2.327 \rightarrow 5 \%$ level of significance; $3.092 \rightarrow 1 \%$ level of significance ${ }^{\mathrm{Ns}}$, not significant (based on $t(4,999)$, one-tailed test). 5,000 bootstrapping procedure used

Table 5.

Weights and significance of formative models

\begin{tabular}{|c|c|c|c|c|c|}
\hline & EXPLOY & EXPSAT & MEM & QOL & \\
\hline \multicolumn{6}{|l|}{ EXPLOY } \\
\hline EXPSAT & 0.705 & & & & \\
\hline MEM & 0.699 & 0.897 & \multirow{2}{*}{\multicolumn{2}{|c|}{0.659}} & \\
\hline QOL & 0.734 & 0.590 & & & Discriminant validity \\
\hline \multicolumn{6}{|c|}{$\begin{array}{l}\text { Notes: EXPQ, experience quality; EXPSAT, experiential satisfaction; MEM, memorability; QOL, quality of } \quad \text { analysis (HTMT1) } \\
\text { life; EXPLOY, experiential Loyalty } \\
\text { (Step 2) }\end{array}$} \\
\hline
\end{tabular}


SJME

24,3

\section{8}

Table 7 .

Effects on endogenous variables

predictive accuracy and the exogenous variables' combined effect on endogenous variables. Its admitted values fluctuate from 0 to 1 . The scores close to the thresholds of 0.75, 0.50 and 0.25 communicate, respectively, a substantial, moderate and weak level of accuracy (Hair et al., 2013). By the other side, paths' coefficients $(\beta)$ show the strength of the relationships among the variables hypothesised in the model (Hair et al., 2014). Values are standardised in a range from -1 to +1 . Significance of the paths is tested with a Bootstrapping procedure and the explained variance of endogenous variables is obtained by multiplying the $\beta$ 's values and the correlation between two variables (Falk and Miller, 1992) (Table 7).

The endogenous variables are explained in a moderate-substantial percentage. EXPQ explains approximately $78 \%$ of MEM of the culinary experience lived. Experience satisfaction is explained by EXPQ (46.3\%) and MEM (35.9\%). These two variables together can determine almost the totality $(82 \%)$ of the variable. Experiential loyalty is determined in its $58.7 \%$ by EXPSAT and QOL, which contribute almost equally with a percentage of, respectively, $28.4 \%$ and $30.2 \% . R^{2}$ confirms that the model boasts a moderate-substantial predictive power. Table 8 shows that the $\beta$ coefficients resulted to be significant, therefore, the hypothesised relationships are empirically supported (Table 8).

\begin{tabular}{|c|c|c|c|c|}
\hline Hypotheses & $R^{2}$ & Direct effect $(\beta)$ & Correlation & $\begin{array}{c}\text { Explained } \\
\text { variance }(\%)\end{array}$ \\
\hline $\begin{array}{l}\text { Memory } \\
H 1_{+}: \mathrm{EXPQ} \rightarrow \mathrm{MEM}\end{array}$ & 0.785 (substantial) & 0.886 & 0.886 & $\begin{array}{l}78.5 \\
78.5\end{array}$ \\
\hline $\begin{array}{l}\text { Experience Satisfaction } \\
H 2_{+}: \mathrm{EXPQ} \rightarrow \text { EXPSAT } \\
H 4_{+}: \mathrm{MEM} \rightarrow \text { EXPSAT }\end{array}$ & 0.822 (substantial) & $\begin{array}{l}0.522 \\
0.411\end{array}$ & $\begin{array}{l}0.887 \\
0.874\end{array}$ & $\begin{array}{l}82.2 \\
46.3 \\
35.9\end{array}$ \\
\hline $\begin{array}{l}\text { Quality of life } \\
H 3_{+}: \mathrm{EXPQ} \rightarrow \mathrm{QOL} \\
H 5_{+}: \mathrm{MEM} \rightarrow \mathrm{QOL}\end{array}$ & 0.435 (weak-moderate) & $\begin{array}{l}0.373 \\
0.306\end{array}$ & $\begin{array}{l}0.644 \\
0.637\end{array}$ & $\begin{array}{l}43.5 \\
24.0 \\
19.4\end{array}$ \\
\hline $\begin{array}{l}\text { Experience loyalty } \\
H 6_{+}: \text {EXPSAT } \rightarrow \text { EXPLOY } \\
H 7_{+}: \text {QOL } \rightarrow \text { EXPLOY }\end{array}$ & 0.587 (moderate-substantial) & $\begin{array}{l}0.422 \\
0.442\end{array}$ & $\begin{array}{l}0.675 \\
0.684\end{array}$ & $\begin{array}{l}58.7 \\
28.4 \\
30.2\end{array}$ \\
\hline
\end{tabular}

Notes: EXPQ, experience quality; EXPSAT, experience satisfaction; MEM, memorability; QOL, quality of life; EXPLOY, experience loyalty

\begin{tabular}{lccl}
\hline Hypotheses & Direct effect $(\beta)$ & T statistics (bootstrap) & Hypotheses' test \\
\hline$H 1: E X P Q \rightarrow M E M$ & 0.886 & $56.157^{* * * * *}$ & Supported \\
$H 2: E X P Q \rightarrow E X P S A T$ & 0.522 & $7.748^{* * * * *}$ & Supported \\
$H 3: E X P Q \rightarrow Q O L$ & 0.373 & $4.511^{* * * * *}$ & Supported \\
$H 4: M E M \rightarrow E X P S A T$ & 0.411 & $5.944^{* * * *}$ & Supported \\
H5: $M E M \rightarrow$ QOL & 0.306 & $3.513^{* * * *}$ & Supported \\
$H 6: E X P S A T \rightarrow E X P L O Y$ & 0.422 & $6.464^{* * * *}$ & Supported \\
$H 7:$ QOL $\rightarrow$ EXPLOY & 0.442 & $8.181^{* * * *}$ & Supported
\end{tabular}

Table 8.

Structural model results
Notes: EXPQ, experience quality; EXPSAT, experience satisfaction; MEM, memorability; QOL, quality of life; EXPLOY, experience Loyalty *Critical values for a one-tailed $t$ test: $t$-values: $* p<0.05$; $* * p<0.01$ $p<0.001$; ns not significant (based on $t(4,999)$, one-tailed test); $t(0.05 ; 4,999)=1.645 ; t(0.01 ; 4,999)=2.327$; $t(0.001 ; 4,999)=3.0925,000$ bootstrapping procedure used 
The results recorded for both measurement and structural model analysis are graphically presented in Figure 2.

\section{Discussion of results}

The results show the importance of offering experiential value within the context of culinary tourism. The model shows a substantial-moderate capacity to explain the endogenous variables considered (Table 8). EXPQ resulted to be a strong predictor of MEM, explaining the $78.5 \%$ of its variance. Path coefficient from EXPQ to MEM is highly significant $(\beta$ : $0.886^{* * *}$ ). Previous studies suggest the conceptual links existing between EXPQ and MEM (Pizam, 2010), but their direct causal relationship has never been supported by empirical evidence. Thus, the results achieved here represent an original outcome, confirming that experiential aspects of tourism services' quality are fundamental requirements to provide memorable experiences to consumers, which, in turn, is proved to have direct and indirect effects on satisfaction and loyalty. Moreover, EXPQ is the fund to be a good antecedent and has a positive causal relationship over two experiential outcomes: EXPSAT $\left(R^{2}: 46.3 \% ; \beta\right.$ : $\left.0.522^{* * *}\right)$ and QOL $\left(R^{2}: 24.0 \% ; \beta: 0.373^{* * *}\right)$. These results are in line with the findings of Wu and colleagues (Wu and Ai, 2016; Wu et al., 2018), Kao et al. (2008) and Jin et al. (2015) who confirmed the EXPQ and EXPSAT connection in the context, respectively, of golf tourism, theme parks and water parks. This research adds to this knowledge confirming this causal path in the culinary food context. MEM is the major determinant of EXPSAT, explaining the $46.5 \%$ of its total explained variance $(80 \%)$. The causality path that links these two variables is significant $(\beta: 0.411)$ confirming the influence of memorability on the positive evaluation of tourism experiences. Therefore, in line with previous scientific results

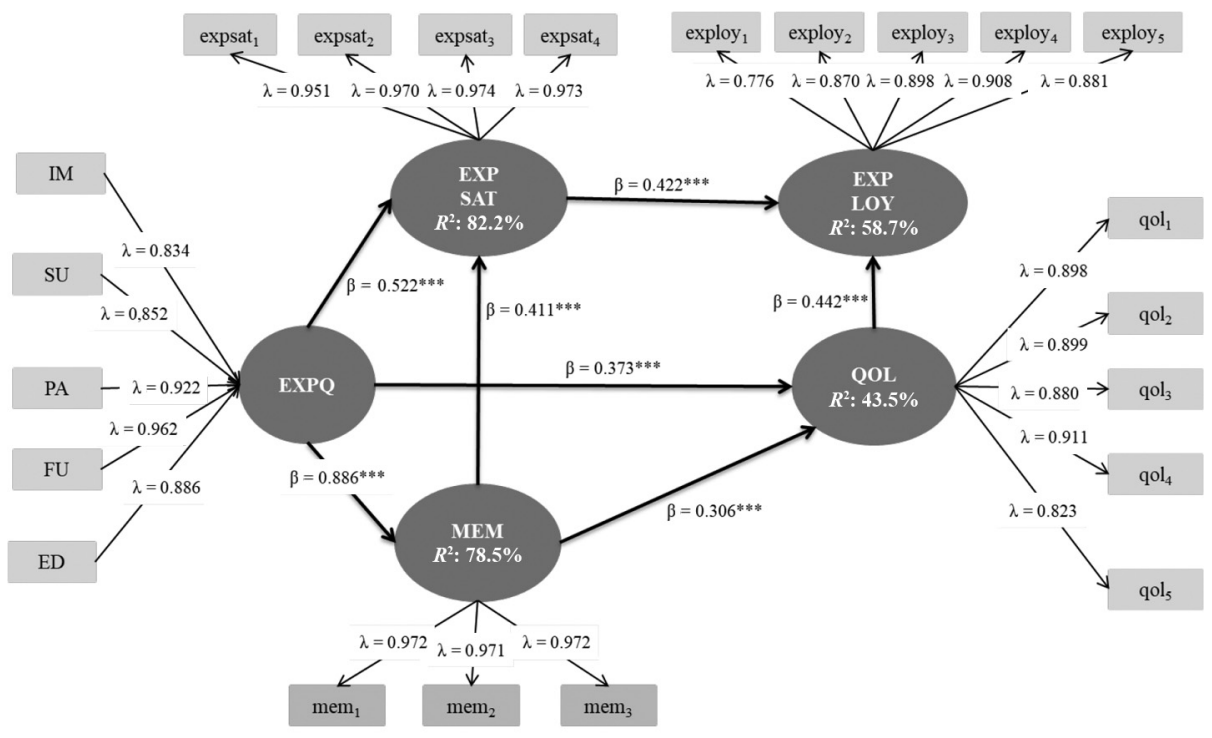

Notes: IM, immersion; SU, surprise; PA, participation; FU, fun; ED, education; EXPQ, experience quality; EXPSAT, experiential satisfaction; MEM, memorability; QOL, quality of life; EXPLOY, experiential loyalty. $R^{2}=$ variable's explained variance; $\lambda=$ item's loadings; $\beta=$ direct effect
Culinary travel experiences

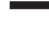


(Ali et al., 2016; Quadri-Felitti and Fiore, 2013), within the experiential context, MEM is confirmed as a germane attribute for achieving the tourists' satisfaction. The causal relationship between MEM and QOL has found empirical support $\left(\beta: 0.306^{* *}\right)$, which is in line with similar outcomes achieved by Lin (2014) and Sthapit (2018) confirming that foodbased experiences contribute to tourists' QOL through memories. EXPLOY is well explained $\left(R^{2}: 58.7 \%\right)$ by both EXPSAT and QOL. The causal path linking this variable resulted to be significant $\left(H_{6}, \beta: 0.422^{* * *} ; H_{7}, \beta: 0.442^{* * *}\right)$ confirming that experiential satisfaction and QOL have a positive impact on EXPLOY, that is, the tourists' intention to repeat a similar experience in future holidays. These results, by the one side, prove a largely studied relationship in tourism literature: the one between satisfaction and loyalty (Chi and $\mathrm{Qu}, 2008$; Cronin et al., 2000) and, by the other side, provide further evidences for a recently explored causal path linking QOL and future behavioural intentions. The findings of this study are in line with similar outcomes achieved by Kim et al. (2015), Lam and So (2013), Lin (2014) and Kim et al. (2012). However, it is also an original output, in comparison with previous findings, as this research considers loyalty with an innovative approach, focussed on the tourists' intentions to patronise a specific experience (food-based) in their next travels and trips.

\section{Conclusions and management implications}

In this research, it is explored how the experientiality of culinary activities practiced while on holidays positively contribute to marketing outcomes such as satisfaction, QOL and loyalty. This study contributes to the literature on experiential tourism by providing insights into new or little-explored relationships, such as those linking EXPQ, MEM, QOL and EXPLOY, in a food tourism context.

The results achieved shed some new light on the experientiality issue in tourism, that is, how to deliver experiential value to tourists. Culinary experiences are considered as proper objects to develop experiential encounters at a destination as they elicit positive emotions and feelings that last beyond the journey.

The theoretical arrangement of the present research considered that the experiential quality of food-tourism activities, practiced on holidays, provide memorable experiences capable of improving individuals' QOL, which in turn fosters tourists' satisfaction and drives future behaviour intentions. The empirical test of the structural model confirmed the hypothesised relationships and showed a good predictive power of the model. The results of the research lead to the following conclusions and practical implications for the sector:

- EXPQ is a central element in delivering MEM (Pizam, 2010) and satisfaction (Widjaja et al., 2018) to culinary tourists who look for experiential values. In addition, this research confirms an original connection linking EXPQ and QOL.

- The assessment of EXPQ lived depends on how surprising, funny, engaging and educative the proposed activities are (Kao et al., 2008; Cole and Scott, 2004). The educational facet of the experience is the seed capable of enhancing memories and driving future positive behaviours (Sthapit et al., 2017).

- Food and food-based activities are resources particularly given to generate good memories (Stone et al., 2017). The results achieved in reference with the MEM variable should encourage marketers to formulate strategies that reinforce the memorable value of their tourism proposals. Practitioners should recognise the role of food-based activities as memory and QOL's enhancers and try to get the advantage of it by drawing new offerings capable of impacting the consumers' memory, beyond the holidays' time. 
- QOL is confirmed as a significant antecedent of EXPLOY. The perception that a specific experience lived on holidays can have a positive effect on personal QOL is confirmed to be a valuable predictor of the intentions to repurchase a similar experience in future travels and destinations (Lin, 2014). This result puts forward the need of a new conceptualisation of loyalty in tourism, no longer linked to the destination or a specific service, but rather to the kind of the experience itself (Pearce and Kang, 2009). This can help in clustering tourists according to the type of experience they feel loyal to. As a consequence, destination's managers and Culinary travel experiences practitioners can outline experiential marketing strategies focussed on the group of tourists they wish to attract according to the kind of experience they usually patronise in their trips or holidays.

In conclusion, food-based experiences are identified as new essential tools for the sector's qualification towards experientiality. Destination managers can find the results achieved of help in designing new experiential offerings and can lead tourism practitioners in the challenge of increasing the tourism industry's competitiveness.

Quality is increasingly expected to focus on emotional/subjective values more than on functional/objective attributes of the service/product. MEM and QOL are innovative elements that can contribute, by the one side, to the achievement of a better performance of tourism businesses, and by the other, to reaching higher levels of satisfaction and new loyal attitudes towards a specific in-trip typology of activities.

The main limitation of this work is the use of a non-probabilistic sampling strategy, which affects the generalisability of the results. Future research lines should consider a qualitative approach to get a deeper understanding of the tourists' assessments of the experiential variables considered. In addition, it would be useful to add knowledge to the research on EXPQ, to achieve a better understanding of its components/facets, and on MEM with empirical works addressing whether the memories of outstanding food-based experiences lived on holidays can impact the positive evaluations of individuals' QOL over the long term.

\section{References}

Adongo, C.A., Anuga, S.W. and Dayour, F. (2015), "Will they tell others to taste? International tourists' experience of Ghanaian cuisines", Tourism Management Perspectives, Vol. 15, pp. 57-64.

Agapito, D., Mendes, J. and Valle, P. (2013), "Exploring the conceptualization of the sensory dimension of tourist experiences", Journal of Destination Marketing and Management, Vol. 2 No. 2, pp. 62-73.

Ali, F., Ryu, K. and Hussain, K. (2016), "Influence of experiences on memories, satisfaction and behavioral intentions: a study of creative tourism", Journal of Travel and Tourism Marketing, Vol. 33 No. 1, pp. 85-100.

Alves, H., Campón-Cerro, A.M. and Hernández-Mogollón, J.M. (2019), "Enhancing rural destinations' loyalty through relationship quality", Spanish Journal of Marketing - ESIC, Vol. 23 No. 2, pp. 185-204.

Aziz, N.A., Ariffin, A.A.M., Osmar, N.A. and Evin, C. (2012), "Examining the impact of visitors' emotions and perceived quality towards satisfaction and revisit intention to theme parks", Jurnal Pengurusan, Vol. 35, pp. 97-109.

Baah, N.G., Bondzi-Simpson, A. and Ayeh, J.K. (2019), "How neophilia drives international tourists' acceptance of local cuisine", Current Issues in Tourism, doi: 10.1080/13683500.2019.1619676. 
Bigné, E., Mattila, A.S. and Andreu, L. (2008), “The impact of experiential consumption cognitions and emotions on behavioral intentions", Journal of Services Marketing, Vol. 22 No. 4, pp. 303-315.

Björk, P. and Kauppinen-Räisänen, H. (2016), "Exploring the multi-dimensionality of travellers' culinary-gastronomic experiences", Current Issues in Tourism, Vol. 19 No. 12, pp. 1260-1280.

Carmines, E.G. and Zeller, R.A. (1979), Reliability and Validity Assessment, Sage Publications, Beverly Hills/London.

Carrillo, E., Prado-Gascó, V., Fiszman, S. and Varela, P. (2013), "Why buying functional foods? Understanding spending behaviour through structural", Food Research International, Vol. 50 No. 1, pp. 361-368.

Castañeda García, J., Del Valle Galindo, A. and Martínez Suárez, R. (2018), "The effect of online and offline experiential marketing on Brand equity in the hotel sector", Spanish Journal of Marketing-ESIC, Vol. 22 No. 1, pp. 22-41.

Chen, C.-F. and Chen, F.-S. (2010), "Experience quality, perceived value, satisfaction and behavioral intentions for heritage tourists", Tourism Management, Vol. 31 No. 1, pp. 29-35.

Chen, C.-F. and Chen, P.-C. (2013), "Another look at the heritage tourism experience”, Annals of Tourism Research, Vol. 41, pp. 236-240.

Chen, C.-C. and Petrick, J.F. (2016), "The roles of perceived travel benefits, importance, and constraints in predicting travel behavior", Journal of Travel Research, Vol. 55 No. 4, pp. 509-522.

Chen, C.C., Petrick, J.F. and Shahvali, M. (2016), "Tourism experiences as a stress reliever: examining the effects of tourism recovery experiences on life satisfaction", Journal of Travel Research, Vol. 55 No. 2, pp. 150-160.

Chi, C.G.Q. and Qu, H. (2008), "Examining the structural relationships of destination image, tourist satisfaction and destination loyalty: an integrated approach", Tourism Management, Vol. 29 No. 4, pp. 624-636.

Clatworthy, S.D. (2019), The Experience Centric Organization. How to Win Through Customer Experience, O'Reilly, Boston.

Cole, S.T. and Scott, D. (2004), "Examining the mediating role of experience quality in a model of tourist experiences", Journal of Travel and Tourism Marketing, Vol. 16 No. 1, pp.79-90.

Cronin, J.J., Brady, M.K. and Hult, G.T.M. (2000), "Assessing the effects of quality, value, and customer satisfaction on consumer behavioral intentions in service environments", Journal of Retailing, Vol. 76 No. 2, pp. 193-218.

de Rojas, C. and Camarero, C. (2008), "Visitors' experience, mood and satisfaction in a heritage context: evidence from an interpretation center", Tourism Management, Vol. 29 No. 3, pp. 525-537.

Di-Clemente, E., Hernández-Mogollón, J.M. and Campón- Cerro, A.M. (2019a), “Tourists' involvement and memorable food-based experiences as new determinants of behavioural intentions towards typical products", Current Issues in Tourism, doi: 10.1080/13683500.2019.1631265.

Di-Clemente, E., Hernández-Mogollón, J.M. and Campón- Cerro, A.M. (2019b), "Food-based experiences as antecedents of destination loyalty", British Food Journal, Vol. 121 No. 7, pp. 1495-1507.

Dolnicar, S., Lazarevski, K. and Yanamandram, V. (2013), "Quality of life and tourism: a conceptual framework and novel segmentation base", Journal of Business Research, Vol. 66 No. 6, pp. 724-729.

Dong, P. and Siu, N.Y.-M. (2013), "Servicescape elements, customer predispositions and service experience: the case of theme park visitors", Tourism Management, Vol. 36, pp. 541-551.

Falk, R.F. and Miller, N.B. (1992), A Primer for Soft Modeling, The University of Akron, Akron, OH.

Fernandes, T. and Cruz, M. (2016), "Dimensions and outcomes of experience quality in tourism: the case of port wine cellars", Journal of Retailing and Consumer Services, Vol. 31, pp. 371-379.

Flavián, C., Martínez, E. and Polo, Y. (2011), "Loyalty to grocery stores in the Spanish market of the 1990s”, Journal of Retailing and Consumer Services, Vol. 8 No. 2, pp. 85-93. 
Fox, R. (2007), "Reinventing the gastronomic identity of Croatian tourist destinations", International Journal of Hospitality Management, Vol. 26 No. 3, pp. 546-559.

Franke, G. and Sarstedt, M. (2019), "Heuristics versus statistics in discriminant validity testing: a comparison of four procedures", Internet Research, Vol. 29 No. 3, pp. 430-447.

Goolaup, S., Sóler, C. and Nunkoo, R. (2017), "Developing a theory of surprise from travelers' extraordinary food experiences”, Journal of Travel Research, Vol. 57 No. 2, pp. 218-231.

Hair, J.F., Ringle, C.M. and Sarstedt, M. (2011), "PLS-SEM: indeed a silver bullet”, Journal of Marketing Theory and Practice, Vol. 19 No. 2, pp. 139-151.

Hair, J.F., Ringle, C.M. and Sarstedt, M. (2013), "Partial least squares structural equation modeling: rigorous applications, better results and higher acceptance", Long Range Planning, Vol. 46 Nos 1/2, pp. 1-12.

Hair, J.F., Anderson, R.E., Tatham, R.L. and Black, W.C. (1995), Multivariate Data Analysis, (3rd ed.), Macmillan, New York, NY.

Hair, J.F., Hult, G.T.M., Ringle, C.M. and Sarstedt, M. (2014), Primer on Partial Least Squares Structural Equation Modeling (PLS-SEM), Sage, Thousand Oaks.

Hair, J.F., Sarstedt, M., Ringle, C.M. and Mena, J.A. (2012), "An assessment of the use of partial least squares structural equation modeling in marketing research", Journal of the Academy of Marketing Science, Vol. 40 No. 3, pp. 414-433.

Hall, C.M., Sharples, L., Mitchell, R., Macionis, N. and Cambourne, B. (2003), Food around the World. Development, Management and Markets, Butterworth-Heinemann, Oxford.

Henseler, J., Ringle, C. and Sinkovics, R. (2009), "The use of partial least squares path modeling in international marketing", Advances in International Marketing, Vol. 20, pp. 277-320.

Hjalager, A.-M. and Johansen, P.H. (2013), "Food tourism in protected areas - sustainability for producers, the environment and tourism?”, Journal of Sustainable Tourism, Vol. 21 No. 3, pp. 417-433.

Hosany, S. (2012), "Appraisal determinants of tourist emotional responses", Journal of Travel Research, Vol. 51 No. 3, pp. 303-314.

Hosany, S. and Gilbert, D. (2010), "Measuring tourists' emotional experiences toward hedonic holiday destinations", Journal of Travel Research, Vol. 49 No. 4, pp. 513-526.

Hosany, S. and Witham, M. (2010), "Dimensions of cruisers' experiences, satisfaction, and intention to recommend", Journal of Travel Research, Vol. 49 No. 3, pp. 351-364.

Ignatov, E. and Smith, S. (2006), "Segmenting Canadian culinary tourists", Current Issues in Tourism, Vol. 9 No. 3, pp. 235-255.

Jin, N., Lee, S. and Lee, H. (2015), "The effect of experience quality on perceived value, satisfaction, image and behavioral intention of water park patrons: New versus repeat visitors", International Journal of Tourism Research, Vol. 17 No. 1, pp. 82-95.

Kane, K., Chiru, C. and Ciuchete, S.G. (2012), "Exploring the eco-attitudes and buying behaviour of Facebook users", The AMFITEATRU ECONOMIC Journal, Vol. 14 No. 31, pp. 157-171.

Kao, Y.-F., Huang, L.-S. and Wu, C.-H. (2008), "Effects of theatrical elements on experiential quality", Asia Pacific Journal of Tourism Research, Vol. 13 No. 2, pp. 163-174.

Kim, J.-H. (2010), "Determining the factors affecting the memorable nature of travel experience", Journal of Travel and Tourism Marketing, Vol. 27 No. 8, pp. 780-796.

Kim, J.-H. and Ritchie, J.R.B. (2014), "Cross-cultural validation of a memorable tourism experience scale (MTES)", Journal of Travel Research, Vol. 53 No. 3, pp. 323-335.

Kim, Y.G., Eves, A. and Scarles, C. (2009), "Building a model of local food consumption on trips and holidays: a grounded theory approach”, International Journal of Hospitality Management, Vol. 28 No. 3, pp. 423-431. 
Kim, I., Jeon, S.M. and Hyun, S.S. (2012), “Chain restaurant patrons' well-being perception and dining intentions the moderating role of involvement", International Journal of Contemporary Hospitality Management, Vol. 24 No. 3, pp. 402-429.

Kim, H., Woo, E. and Uysal, M. (2015), “Tourism experience and quality of life among elderly tourists”, Tourism Management, Vol. 46, pp. 465-476.

Kivela, J. and Crotts, J.C. (2006), "Tourism and gastronomy: Gastronomy's influence on how tourists experience a destination", Journal of Hospitality and Tourism Research, Vol. 30 No. 3, pp. 354-377.

Knobloch, U., Robertson, K. and Aitken, R. (2017), "Experience, emotion, and eudaimonia: a consideration of tourist experiences and well-being", Journal of Travel Research, Vol. 56 No. 5 , pp. 651-662.

Komppula, R. (2006), "Developing the quality of a tourist experience product in the case of nature-based activity services", Scandinavian Journal of Hospitality and Tourism, Vol. 6 No. 2, pp. 136-149.

Kruger, S., Rootenberg, C. and Ellis, S. (2013), "Examining the influence of the wine festival experience on tourists' quality of life", Social Indicators Research, Vol. 111 No. 2, pp. 435-452.

Lam, D. and So, A. (2013), "Do happy tourists spread more word-of-mouth? The mediating role of life satisfaction”, Annals of Tourism Research, Vol. 43, pp. 646-650.

Lashley, C. (2008), "Marketing hospitality and tourism experiences", in Oh, H. and Pizam, A. (Eds), Handbook of Hospitality Marketing Management, Butterworth- Heinemann, Oxford, pp. 3-31.

Lin, C.-H. (2014), "Effects of cuisine experience, psychological well-being, and self-health perception on the revisit intention of hot spring tourists", Journal of Hospitality and Tourism Research, Vol. 38 No. 2, pp. 243-265.

López-Guzmán, T. and Sánchez-Cañizares, S. (2012), "Culinary tourism in Córdoba (Spain)”, British Food Journal, Vol. 114 Nos 2/3, pp. 168-179.

Loureiro, S.M. (2014), "The role of the rural tourism experience economy in place attachment and behavioral intentions", International Journal of Hospitality Management, Vol. 40, pp. 1-9.

McKercher, B., Denizci-Guillet, B. and Ng, E. (2012), "Rethinking loyalty", Annals of Tourism Research, Vol. 39 No. 2, pp. 708-734.

Mason, M.C. and Paggiaro, A. (2009), "Celebrating local products: the role of food events", Journal of Foodservice Business Research, Vol. 12 No. 4, pp. 364-383.

Mechinda, P., Serirat, S. and Gulid, N. (2009), "An examination of tourists' attitudinal and behavioral loyalty: comparison between domestic and international tourists", Journal of Vacation Marketing, Vol. 15 No. 2, pp. 129-148.

Mkono, M., Markwell, K. and Wilson, E. (2013), "Applying Quan and Wang's structural model of the tourist experience: a Zimbabwean netnography of food tourism", Tourism Management Perspectives, Vol. 5, pp. 68-74.

Nawijn, J. (2011), "Happiness through vacationing: just a temporary boost or long-term benefits?", Journal of Happiness Studies, Vol. 12 No. 4, pp. 651-665.

Nawijn, J., Marchand, M.A., Veenhoven, R. and Vingerhoets, A.J. (2010), "Vacationers happier, but most not happier after a holiday”, Applied Research in Quality of Life, Vol. 5 No. 1, pp. 35-47.

Nawijn, J., Mitas, O., Lin, Y. and Kerstetter, D. (2013), "How do we feel on vacation? A closer look at how emotions change over the course of a trip", Journal of Travel Research, Vol. 52 No. 2, pp. 265-274.

Nunnally, J.C. and Bernstein, I. (1994), Psychometric Theory, McGraw-Hill, New York, NY.

Oh, H., Fiore, A.M. and Jeoung, M. (2007), "Measuring experience economy concepts: tourism applications", Journal of Travel Research, Vol. 46 No. 2, pp. 119-132.

Oliver, R. (1993), "Cognitive, affective, and attribute bases of the satisfaction response”, Journal of Consumer Research, Vol. 20 No. 3, pp. 418-430. 
Palmer, A. (2010), "Customer experience management: a critical review of an emerging idea", Journal of Services Marketing, Vol. 24 No. 3, pp. 196-208.

Pearce, P.L. and Kang, M.-H. (2009), "The effects of prior and recent experience on continuing interest in tourist settings", Annals of Tourism Research, Vol. 36 No. 2, pp. 172-190.

Pizam, A. (2010), "Creating memorable experiences", International Journal of Hospitality Management, Vol. 29 No. 3, pp. 343.

Preston, C.C. and Colman, A.M. (2000), "Optimal number of response categories in rating scales: reliability, validity, discriminating power, and respondent preferences", Acta Psychologica, Vol. 104 No. 1, pp. 1-15.

Quadri-Felitti, D.L. and Fiore, A.M. (2013), "Destination loyalty: effects of wine tourists' experiences, memories, and satisfaction on intentions", Tourism and Hospitality Research, Vol. 13 No. 1, pp. $47-62$.

Richards, G. (2012), "Food and the tourism experience", in WTO (Ed.), Global Report on Food Tourism, UNWTO, Madrid, pp. 20-21.

Ringle, C.M., Wende, S. and Becker, J.-M. (2015), SmartPLS 3, SmartPLS GmbH, Boenningstedt, available at: www.smartpls.com

Roberts, N. and Thatcher, J.B. (2009), "Conceptualizing and testing formative constructs: tutorial and annotated example", Acm Sigmis Database: The Database for Advances in Information Systems, Vol. 40 No. 3, pp. 9-39.

Serra-Cantallops, A., Ramón-Cardona, J. and Savini, F. (2018), "The impact of positive emotional experiences on eWOM generation and loyalty", Spanish Journal of Marketing - ESIC, Vol. 22 No. 2, pp. 142-162.

Sirgy, M.J., Kruger, P.S., Lee, D.-J. and Yu, G.B. (2011), "How does a travel trip affect tourists' life satisfaction?”, Journal of Travel Research, Vol. 50 No. 3, pp. 261-275.

Sthapit, E. (2018), "Is there more to the effects of tourists' local food consumption on post consumption behaviour?", Anatolia, Vol. 29 No. 4, pp. 614-616.

Sthapit, E. and Coudounaris, D.N. (2017), "Memorable tourism experiences: antecedents and outcomes", Scandinavian Journal of Hospitality and Tourism, Vol. 18 No. 1, pp. 72-94.

Sthapit, E., Björk, P. and Coudounaris, D.N. (2017), "Emotions elicited by local food consumption, memories, place attachment and behavioural intentions", Anatolia, Vol. 28 No. 3, pp. 363-380.

Stone, M.J., Migacz, S. and Wolf, E. (2019), "Beyond the journey: the lasting impact of culinary tourism activities", Current Issues in Tourism, Vol. 22 No. 2, pp. 147-152.

Stone, M.J., Soulard, J., Migacz, S. and Wolf, E. (2017), "Elements of memorable food, drink, and culinary tourism experiences", Journal of Travel Research, Vol. 57 No. 8, pp. 1121-1132.

Tsai, C.-T. (2016), "Memorable tourist experiences and place attachment when consuming local food", International Journal of Tourism Research, Vol. 18 No. 6, pp. 536-548.

Uysal, M., Sirgy, M.J., Woo, E. and Kim, H.L. (2016), "Quality of life (QOL) and well-being research in tourism”, Tourism Management, Vol. 53, pp. 244-261.

Veenhoven, R. (2009), "The international scale interval study: improving the comparability of responses to survey questions about happiness", in Møller, V. and Huschka, D. (Eds), Quality of Life in the New Millennium: Advances in Quality-of-Life Studies, Theory and Research, Springer, Dordrecht, pp. 45-58.

Widjaja, D., Wijaya, S., Jokom, R. and Kristanti, M. (2018), "Culinary and destination experiences of international tourists in Bandung and solo: the effect on behavioral intentions", Advances in Economics, Business and Management Research, Vol. 69, pp. 183-187.

Wijaya, S., King, B., Morrison, A. and Nguyen, T.-H. (2017), "Destination encounters with local food: the experience of international visitors in Indonesia", Tourism Culture and Communication, Vol. 17 No. 2, pp. 79-91. 
SJME

24,3

Williams, A. (2006), “Tourism and hospitality marketing: fantasy, feeling and fun”, International Journal of Contemporary Hospitality Management, Vol. 18 No. 6, pp. 482-495.

Williams, H.A., Yuan, J. and Williams, R.L. (2018), "Attributes of memorable gastro-tourists' experiences”, Journal of Hospitality and Tourism Research, Vol. 43 No. 3, pp. 327-348.

Wu, H.-C. and Ai, C.-H. (2016), "Synthesizing the effects of experiential quality, excitement, equity, experiential satisfaction on experiential loyalty for the golf industry: the case of Hainan island", Journal of Hospitality and Tourism Management, Vol. 29, pp. 41-59.

Wu, H.-C. and Li, T. (2017), "A study of experiential quality, perceived value, heritage image, experiential satisfaction and behavioral intentions for heritage tourism”, Journal of Hospitality and Tourism Research, Vol. 41 No. 8, pp. 904-944.

Wu, H.-C., Li, M.-Y. and Li, T. (2018), "A study of experiential quality, experiential value, experiential satisfaction, theme park image, and revisit intention", Journal of Hospitality and Tourism Research, Vol. 42 No. 1, pp. 26-73.

\section{Corresponding author}

Elide Di-Clemente can be contacted at: ediclemente@unex.es

For instructions on how to order reprints of this article, please visit our website: 